MENDELU Working Papers

in Business and Economics

$77 / 2021$

Political Insider Trading:

A narrow versus comprehensive approach

Jan Hanousek, Jr., Christos Pantzalis, Jung Chul Park 


\title{
Political Insider Trading: A narrow versus comprehensive approach
}

\author{
Jan Hanousek, Jr.", Christos Pantzalis**, and Jung Chul Park ${ }^{\dagger}$
}

\begin{abstract}
We examine senators' electronically filed stock transactions between 2012 and 2019 to assess the extent of politician's insider trading. Our results suggest that senators use inside political information when investing and earn significant market-adjusted returns. To extend traditional return-based methods, we propose a new comprehensive approach based on abnormal idiosyncratic volatility (AIV), which captures the degree of information asymmetry around their trading dates. We document that senator trades are associated with substantially high levels of AIV, suggesting that they represent only a tip of the iceberg, since the mass of unfiled transactions using the same inside information remains undetected.
\end{abstract}

Keywords: Abnormal idiosyncratic volatility, legislator's trading, politician's insider trading, STOCK Act

JEL Classification: C58, G12, G14, G28

* Corresponding author. Kate Tiedemann School of Business and Finance, Muma College of Business, University of South Florida, and Faculty of Business and Economics, Department of Finance, Mendel University in Brno, Czech Republic. Address: Muma College of Business, University of South Florida, BSN3403, Tampa, FL 33620. Tel: 1813-377-7568, E-mail: janhanousek@usf.edu.

** Kate Tiedemann School of Business and Finance, Muma College of Business, BSN3403, University of South Florida, Tampa, FL 33620, Tel: 1-813-974-3262, E-mail: cpantzal@usf.edu.

$\dagger$ Kate Tiedemann School of Business and Finance, Muma College of Business, BSN3403, University of South Florida, Tampa, FL 33620, Tel: 1-813-974-9680, E-mail: jpark5 @usf.edu.

We are grateful to Stephen Ferris, Randall Filer, Jan Hanousek, Svatopluk Kapounek, and seminar participants at the University of South Florida, MME 2020, and CSE for insightful comments that greatly improved earlier versions of this paper. The opinions expressed in this article are the authors' own and do not reflect the view of the affiliated institutions. 


\section{Introduction}

Are politicians taking advantage of their access to superior information when they trade in the markets? Despite the importance of the issue from the perspective of regulators, market participants, and the general public, the extant literature provides a range of views on the behavior of political insiders, as there are no conclusive ways to identify whether or when a politician acts on inside information. ${ }^{1}$ We revisit this research question using information on electronic filings by members of the US Senate and employing a price-based measure of information risk around politicians' stock trades that allows us to investigate the extent of informed trading and its determinants.

Politicians' preferences for stocks could be motivated by a desire to engage in quid pro quo relations with firms (Tahoun 2014). Thus, the asset holdings of politicians may reflect "latent connections" between firms and politicians. ${ }^{2}$ In an effort to increase transparency and combat insider trading the Senate introduced the Stop Trading on Congressional Knowledge (STOCK) act in April 2012. This act prohibits the use of non public information for profit. However, the overall picture remains cloudy. Kim (2012) points out that the STOCK Act is not binding for all legislators. ${ }^{3}$ Moreover, analysis of the extent of political insider information trading is relatively difficult. First, politicians can earn abnormal profit not necessarily because of corporate insider information, but rather when investing in industries that fall under the jurisdictions of their

\footnotetext{
${ }^{1}$ Using portfolio analysis, Ziobrowski et al. (2004) show that government insiders outperform the market by $10 \%$ per year on average, even beating corporate insiders. However, Eggers and Hainmueller (2014) dispute these claims. They argue that the abnormal returns are caused by the synthetic construction of the portfolio and the actual returns are nowhere near those levels; in fact, they do not beat the market on average.

${ }^{2}$ Such political connections played a role in the bailout decision in the 2008 financial crisis (Duchin \& Sosyura 2012). Accordingly, Hassan et al. (2019) show that politicians who invested in financial institutions were found to be more likely to vote in favor of the Economic Emergency Stabilization Act (EESA) compared with their matched counterpart who did not hold assets in financial institutions.

${ }^{3}$ There were more than 7000 legislators in 2012 that had access to political insider information and could still trade on it without any repercussions after the passing the STOCK act ((Kim 2012). Currently, congressional aides and staffers do not have to disclose their trading activities (Lawder and Cowan (2012)).
} 
committees (Karadas 2018), or even without a committee link when investing in local firms (Eggers and Hainmueller 2014). Second, most of the current literature on government insiders fails to take into account differences in financial know-how between corporate and government insiders. The latter, e.g., a legislator, can use his inside information to make an informed trade, but lack of knowledge might prevent him from making the level of abnormal returns achieved by a financial analyst trading on the same information. Lastly, the current literature overlooks one major fact. The number of (federal-level) politicians and legislators that have to file their securities transactions is much smaller than the number of politicians and legislators (e.g., at the state level), staff members, and lobbyists who may also have access to legislative knowledge and political insider information. Therefore, the trading activity of senators (and potentially House members) should be viewed as proxy for that of all others who have access to the same information, but do not file their transactions (Kim 2012).

The motivation for this paper is to build on prior studies by expanding the investigation of politically informed trading. In addition to analyzing the buy and hold abnormal returns of securities traded by politicians, we also propose a different approach to analyzing abnormal trade activity or potential insider trading by politicians. We utilize abnormal idiosyncratic volatility (AIV), a price-based measure of information risk, to provide insight on the extent of informed trading around dates when senators purchase stocks.

We use unique post STOCK Act data of senator's transaction reports for our analysis. As part of the STOCK Act, senators and their immediate family have to list transactions of all securities, specify the type of the security, direction of the trade and categorize the size of the transaction. We combine this data with hand-collected information about senators, which allows us to control for senator characteristics including age, tenure, state, and important committee 
memberships, among others. Our results show that stocks purchased by senators beat the market over the 2-3 month period following the date of the trade. Another indication that senators purchases are often driven by superior information is that they also outperform their recent sales by a significant margin. Moreover, periods around dates when senators trade stocks are associated with high levels of information risk (AIV), which implies that many more people are trading on congressional knowledge. The extent of information asymmetry around senators stock transactions is associated with senator personal characteristics (including age, tenure, and important committee membership), and legislative activity of both the senator and the congress overall. Many of the same factors seem to explain the buy and hold market adjusted returns of stocks purchased by senators. In sum, the evidence paints a rather clear picture of how politically informed trading manifests itself into stock prices. Our findings suggest that politicians' trades can be viewed as indicators of latent politically informed trading by others who do not have to file their stock trades. Finally, given that politicians can choose to forgo electronic filing of their trades for a paper filing format that is much harder to scrutinize, the results we document should be regarded as a lower bound of the extent of political insider trading.

This paper contributes to the current literature in the following aspects. Firstly, we provide novel evidence of political insider trading and a new method to detect it. Prior literature focuses on analysis of senator portfolios and of excess returns (See e.g., Ziobrowski et al. 2004; Hainmueller \& Eggers 2014) and to the best of our knowledge, this paper is the first to analyze the extent of informed trading associated with periods of politicians' transactions. Secondly, our paper contributes to the literature that studies price-based measures of information risk (See e.g., Yang et al. 2020) by showing that politicians' trades can reveal previously unaccounted for levels of information asymmetry. Thirdly, our findings have both political and regulatory implications and 
call for both greater scrutiny of politicians' trades as well as an expansion of the set of political actors required to file their stock trades.

This paper is structured as follows: Section 2 summarizes previous research on political insider trading and its detection. Section 3 describes the methodology used and specifies testable versions of hypotheses. In Section 4 we describe the data collection process and report summary statistics. We report our results in Section 5 and discuss the sale transactions in Section 6. Finally, Section 7 concludes.

\section{Related literature and hypothesis development}

\subsection{Politicians and insider information trading}

While the problem of corporate insider trading has long been known, the attention given to political insider trading is much more recent. In one of the first mentions of the problem, Boller and Ward (1995) show that out of a random sample of 111 members of Congress and Senate, $25 \%$ of members' stock transactions were directly linked with legislative activity. It is, however, important to note that the authors only show a potential conflict of interest, but their results do not demonstrate whether the politicians' investments yielded abnormal returns.

This early paper led to several attempts to quantify the performance of politicians' stock investments, and to answer the question of whether they make abnormal profits. Ziobrowski et al. (2004) analyzed stock transactions of US senators between 1993 and 1998 and show that senators outperform the market by approximately $10 \%$ per year. However, Eggers and Hainmueller (2014) paint a very different picture. They use transaction data of Congress members between 2004 and 2008 and show that Congress members underperform the market by, on average, $2-3 \%$ annually. 
However, using pre-STOCK Act data can give conflicting results depending on the time period, because "it is also possible that members simply stopped reporting their incriminating transactions once they realized that academics and the media were watching them" (Kim 2013a p.170).

Since the introduction of the STOCK Act in 2012, multiple papers have attempted to replicate previous studies using verifiable transaction data. Huang and Xuan (2019) show that in the year following the establishment of the STOCK Act there were no surprise mergers that politicians took advantage of, and suggest that the STOCK Act might actually have stopped politicians' insider information trading. It is, however, important to note that Huang and Xuan (2019) only compare the year after the STOCK Act with the year before, and they only investigate whether politicians took advantage of high profile acquisitions and earnings surprises before they became public information.

Furthermore, Belmont et al. (2020) analyze the buy-and-hold abnormal returns of politicians between March of 2012 and 2020, and they somewhat confirm the previous results of Eggers and Hainmueller (2014) that the actual returns of politicians do not beat the industry-size benchmark. However, their results only indicate that senators are not picking the correct stocks although they are choosing the right industries. Additionally, the fact that the senators are not outperforming industry portfolios does not necessarily mean that others with access to the same information as these politicians (e.g., their staff members or other (state) legislators) are not doing so. Therefore, we must be careful when claiming that politicians do not make abnormal returns using their informational advantage. Finally, it is again important that only a small number of political insiders reports their transactions, and therefore we cannot easily conclude whether the politicians' trades are informed or not. 
Notably, the wide range of results from past studies on the profitability of politicians' portfolios mostly stems from the inherent difference between using hypothetical/possible returns and realized returns, and from using different hold periods in case of hypothetical/possible returns. This disagreement suggests that portfolio analysis might not be an adequate tool to detect the extent of insider information trading. We therefore also consider an alternative test that can help detect insider activity. For example, in the context of corporate insiders, possible information trading can be detected using the Easley and O'hara (1987) measure of probability of information driven trading (PIN). ${ }^{4}$ An alternative avenue for insider trading detection is the measure of abnormal idiosyncratic volatility (AIV), recently introduced by Yang et al. (2020). ${ }^{5}$ AIV compares the volatility during the earnings announcement periods when insider trading is rampant against the rest of the year. ${ }^{6}$ We adopt and adjust AIV by defining it around politicians' trading dates rather than earnings announcement dates. The main advantage of this approach is that it does not require the use of tick data to identify buy and sell signals. Rather, it is based on volatility of residuals from the Fama-French three-factor model (Fama \& French 1993) around the event dates.

Our paper aims to expand previous research on political insider trading (Ziobrowski et al. 2004; Eggers \& Hainmueller 2014; Belmont et al. 2020)), by looking beyond abnormal returns and introducing a more sophisticated method based on a price-based measure of information risk (i.e., the AIV of Yang et al. (2020)) to assess whether politicians are insiders and if their

\footnotetext{
${ }^{4}$ The various modifications of this technique, using a sequence of buy and sell signals, has become a benchmark and is widely used (Hasbrouck 1991; Brennan \& Subrahmanyam 1996; Easley et al. 2001; Aktas et al. 2008; CollinDufresne \& Fos 2015).

${ }^{5}$ To capture the use of insider trading information during the announcement dates they define a new variable called abnormal idiosyncratic volatility, which compares the volatility during the earnings announcement periods against the rest of the year. Their results show that there is a higher level of information asymmetry and insider trading during earning announcement periods and that stocks with higher abnormal idiosyncratic volatility have significantly larger returns in future periods.

${ }^{6}$ There is an abundance of evidence that there is a high volume of insider information trades during those periods (Brennan \& Subrahmanyam 1996; Krinsky \& Lee 1996; Kim \& Verrecchia 1997; Vega 2006; Bamber et al. 2010; Back et al. 2018; Yang et al. 2020).
} 
investments yield, or consistently have the potential to yield, abnormal returns. Our method allows us to gauge the extent of trading stemming from legislative and political inside information and reveal its most relevant factors and possible channels.

\subsection{Empirical Hypotheses}

As a starting point, we analyse market returns of political insiders using buy-and-hold portfolio analysis in order to make comparisons with the findings in previous research.

Hypothesis 1: The average stock returns following politicians' trades beat the market returns.

As a corollary to Hypothesis 1, we also test whether the stock returns following politicians' trades exceed industry returns (Corollary 1). Note that for the analysis of politicians' insider trading the use of hypothetical (buy and hold) returns is prefered to realized (actual) returns of senator's trades. The reason is that realized returns do not have to outperform the market, since senators' information usually only relates to one side of the trade (to buy or to sell). Consequently, by closing out positions (buying or selling) at the wrong time they could potentially "wash out" the proceeds from the informed side of the trade. We then proceed to test the following hypotheses:

Hypothesis 2: Politicians' stock trades occur in periods of higher probability of information-driven trading.

We use abnormal idiosyncratic volatility (AIV) as a proxy for information-driven trading. A corollary to Hypothesis 2 is set to test if AIV associated with politicians' trades is comparable 
to or higher than AIV associated with periods around quarterly earnings annoucements (Yang et al. 2020), i.e., around value-relevant corporate information events with a high probability of insider trading (Corollary 2).

Our third hypothesis is constructed to examine whether politicians are in the first wave of informed traders.

Hypothesis 3: Politicians' trades occur at the start of the periods with high probability of information-driven trading.

We posit that not only are the politicians (i.e. senators) informed, but they also belong to the "first wave of informed traders". If, during the days immediately following dates of politicians' stock trades we observe high abnormal unexplained volatility, this would suggest that members of Capitol Hill trade on non-public information that allows them to make abnormal returns and would oftentimes be in the "first wave of informed traders". Either they would be directly informed, since the future stock price change would be caused by legislative activity they are involved in, or they would be among the first to receive the information because of their line of work (Kim 2013b). Additionally, as (Eggers \& Hainmueller 2014) show, there is a possibility that a senator might receive corporate insider information from firms' lobbying efforts related to legislation before their committees.

Following this hypothesis, we estimate whether informed trading by senators can be associated with their tenure, membership on important committees, and other personal characteristicsis used in previous research (E.g., Ziobrowski et al. 2004). Additionally, since the spouses and children of senators also have to disclose their trades, we can observe if senators try to mask their insider trades by giving information to their family members or potentially by 
trading in their name. This expands on Karadas (2018) who shows that spouses of politicians outperformed the market prior to the STOCK Act. Finally, we expect that the involvement of lobbyists and the level of activity in Congress can also influence the extent of informed trading.

Hypothesis 4: The extent of the political insider trading is related to politician characteristics, the account (self or family member) used to trade and relevant legislative activity around the date of the transaction.

\section{Methodology and testable hypotheses}

In this section, we propose a method that can expand on and complement the existing approach to testing and measuring the extent of insider trading by politicians. Our main research method is based on analysis of abnormal idiosyncratic volatility (AIV), originally introduced by Yang et al. (2020) to capture informed trading activity during value-relevant information events, such as quarterly earnings announcements. We modify their analysis and broaden the scope to capture potential informed trading activity during periods around the dates of senators' transactions. Our approach is based on the recommendation that the AIV measure of information risk "may also be applied to other information events such as merges and acquisitions, product recalls, and patent applications" (Yang et al. (2020), p. 530).

This section is structured as follows. First, in Section 3.1 we propose a modified version of abnormal idiosyncratic volatility, to measure potential insider trading around the trade dates of senators. Section 3.2 is devoted to the testing framework for the return-based hypothesis H1 and Corollary 1. Finally, Section 3.3 lays down the methodology and robustness tests we perform using AIV to test $\mathrm{H} 2$, Corollary $2, \mathrm{H} 3$ and $\mathrm{H} 4$. 


\subsection{Concept of Abnormal Idiosyncratic Volatility (AIV)}

Yang et al. (2020) show that their price-based measure of information risk, abnormal idiosyncratic volatility (AIV), is related to insider trading, institutional trading activities and short selling. They also find that firms with high AIV have both economically and statistically larger returns. Most importantly, they show that there is a positive relationship between the AIV and the size of informed return run-ups before the earnings period. This suggests that some traders are truly informed about the earnings before the public. In addition, they note that the AIV is not as persistent as other firm characteristics.

We modify their measure with a focus on comparing the volatility surrounding the stock transaction dates of politicians to that during the rest of the year. Our modification is driven by the fact that unlike quarterly earnings, where the start of the information event is clearly defined, politicians' trades are not necessarily the "start of the event."

As in Yang et al. (2020), the idiosyncratic volatility is measured on the three-factor model of Fama and French (1993).

$$
R_{i, t}=\alpha_{i}+\beta_{i} M K T_{t}+s_{i} S M B_{t}+h_{I} H M L_{t}+\epsilon_{i, t},
$$

where $R_{i, t}$ is the daily excess return on the stock $i$ at time $t$, MKT is the value-weighted market portfolio excess return over the risk-free rate, SMB is the size factor, and HML is the value factor. To compute abnormal idiosyncratic volatility (AIV) we need to specify the time-windows for the calculations. Following Ali and Hirshleifer (2017) and Yang et al. (2020) we define the 5-day window $(d-2, d+2)$ surrounding the politician's stock trade event $(d)$ to minimize possible noise. The data set is split into the around-the-trade periods (ATT) and their complementary not-aroundtrade (NAT) periods, which denote the whole year before the trade, excluding the ATT days. 
To compute the AIV, we run the Fama-French three-factor regression for each stock using the previous one-year of daily data. We obtain an estimated daily residual $\epsilon_{i}$ and then compute the annualized idiosyncratic volatility of a stock, separately for the ATT and NAT using the following formulae:

$$
\begin{aligned}
& I V_{A T T}=\ln \sqrt{252 \times \frac{\sum_{j \in A T T} \epsilon_{j}^{2}}{n_{A T T}-1}} \\
& I V_{N A T}=\ln \sqrt{252 \times \frac{\sum_{j \in N A T} \epsilon_{j}^{2}}{n_{N A T}-1}},
\end{aligned}
$$

where $l n$ stands for the natural logarithm and $n_{A T T}\left(n_{N A T}\right)$ are the number of days in the aroundthe-trade (not-around-trade) period. Finally, we define the abnormal idiosyncratic volatility (AIV) as the difference between the volatility around the trade (ATT) and the rest of the year (NAT):

$$
A I V=I V_{A T T}-I V_{N A T} .
$$

Note that the AIV is calculated for each stock and trade separately. This approach allows us to estimate the information assymmetry associated with the period surrounding a given trade. It is a proxy for the extent of political insider trading. In contrast with previously-used return analyses of politicians' trades, the AIV-based approach captures unusual stock price patterns around their trades. The STOCK Act was introduced in 2012, mandating that all legislators must disclose their trading activity. However, it was weakened after a short period by an amendment made in 2013. Currently, congressional aides and staffers do not have to disclose their trading activities (Lawder \& Cowan 2012). Using the AIVs around the dates of politicians' stock trades, we may be able to detect informed trading activity by people who do not have to disclose their trading activity but still have access to the same information. 


\subsection{Testing the extent of insider trading using buy-and-hold portfolios of political insiders}

Several papers have attempted to estimate the investment returns of politicians. Ziobrowski et al. (2004) use a technique known as calendar-time transaction-based analysis (Odean 1999). They create portfolios by buying stocks on the same day as the politicians. Portfolio stocks are then sold 12 months later. As mentioned previously, they report that these synthetic portfolios built from politicians' transactions beat a passive market index by $12 \%$ per year in the Senate (1993-1998) and 6\% in the House (1985-2001). However, C. Eggers and Hainmueller (2013) criticize this approach based on the premise that since Congress members do not actually hold these synthetic portfolios, the return on them may be quite different from the return that members earned with their actual portfolios. They note that results from such synthetic portfolios can be highly sensitive and returns can vary significantly across different specifications. C. Eggers and Hainmueller (2013) also adopt calendar-time transaction-based analysis, but for robustness they use several other periods, as well as the alternative asset pricing models such as CAPM and the Four-Factor Carhart model. They also calculate the realized return on investment. Using the data prior to the STOCK Act, they conclude that politicians do not significantly outperform the market.

Consequently, to avoid the criticism associated with a technique that led to the aforementioned divergent conclusions from past studies and to test our Hypothesis 1 (and Corollary 1), we calculate buy-and-hold market-adjusted and industry-adjusted returns over several holding periods, following each politician's stock trade using information from electronic reports of senators from the January 2012-December 2019 period. Let us denote $r_{p}$ the return on the stock investment of the given politician over the period $p$. For the period $p$, we consider $l w$, $2 w, 1 m, 2 m$ and $3 m$, representing periods of one week, two weeks, one month, two months and 
three months, respectively. For each period of buy-and-hold strategy, we define the marketadjusted return on a politician's investment as

$$
R_{m, p}=r_{p}-M K T_{p}
$$

where $p$ stands for the holding period, $1 w$ to $3 m$, i.e., from one week to three months and $M K T_{p}$ denotes market return over the same period. Market return is proxied by the S\&P500 market index. We choose the S\&P500 market index instead of the weighted composite market index used in CAPM since it is a common investors' choice to proxy the market returns and corresponding investment instruments, including low cost ETFs, are widely available for investors.

Similarly to (4), we define the industry-adjusted return by subtracting the industry return over the same period from $r_{p}$. The industry return is proxied by the value-weighted return of the appropriate Fama-French 48 industry portfolio.

Hypothesis 1 on whether or not a politician's investment outperforms the market is formulated as:

$\mathrm{H} 1_{0}: \quad R_{m, p}=0$, alternative hypothesis, $\mathrm{H} 1_{\mathrm{A}}: R_{m, p}>0$.

And the corrollary to Hypothesis 1 for whether or not a politician's investment exceeds the industry portfolio returns can be formulated as:

$\mathrm{C} 1_{0}: \quad R_{i, p}=0$, alternative hypothesis, $\mathrm{C}_{\mathrm{A}}: R_{i, p}>0$, where $R_{i, p}$ denotes industry-adusted returns. Here it is important to mention the differences in results from previous papers. To calculate the actual return is almost impossible for two reasons. Firstly, when politicians report their transactions, they can choose whether it is a (partial) sale or a full sale, but there are no clear definitions. Moreover, because reporting requirements allow the reporting of ranges of total dollars invested instead of exact dollar amounts, a perfect match of buys with sales is almost impossible. Secondly, many politicians "dilute" their transactions, i.e., 
they split their buys and/or sales into several smaller transactions, rather than reporting one large transaction. This means that not only it is difficult to precisely calculate the actual returns, but also larger transactions may sometimes become hidden in market noise. ${ }^{7}$

Fortunately, it is not necessary to rely on calculating realized returns in order to test whether transactions are associated with polititical inside information. For the realized returns to consistently outperform the market, we should assume 1) that politicians are well informed when to enter the position, and 2) that they have enough financial expertise to know when the information is priced in and make a good timing for closing the position. However, if we simply observe that stocks traded by politicians can consistently outperform the market (or the industry) returns over several holding periods, it would be reflective of market inefficiency, suggesting that these trades might be based on political inside information that is not publicly available. ${ }^{8}$

\subsection{Testing the extent of insider trading using estimated AIV}

To test Hypotheses 2 to 4, we employ the information risk measure of AIV with the modifications described in Section 3.1. In Hypothesis 2, we aim to test whether the probability of informed trading (i.e., AIV) is higher during periods surrounding dates with stock transactions by senators. Therefore, we formulate the testable version of the hypothesis as follows.

$\mathrm{H} 2_{0}: A I V \leq 0$. Alternative hypothesis, $\mathrm{H} 2_{\mathrm{A}}: A I V \geq 0$,

Note that, as(Yang et al. 2020) mention, the calculated AIV might be lower than in reality because there may be several potential events each year where information asymmetry plays a role (e.g.,

\footnotetext{
${ }^{7}$ We describe the distribution and magnitude of diluted trades in the data section.

${ }^{8}$ This means that even if we calculate the realized returns of senators and their returns did not perform significantly better than the market, but their hypothetical returns did outperform the market, we could still conclude that senators do have inside information, thanks to which they know when to enter the position.
} 
quarterly earnings, mergers and acquisitions or product recalls) and we do not take those into consideration.

Additionally, as part of our analysis of AIV around senator stock trading dates, we want to compare how the information asymmetry during the senator stock transaction period compares to that around quarterly earnings announcements. Therefore, we calculate abnormal idiosyncratic volatility as defined by Yang et al. (2020) around the quarterly earnings for every year and stock for which a senator transaction took place. We denote this abnormal idiosyncratic volatility as $A I V_{E}$ (earnings), to differentiate from our calculated measure. We can then reformulate the supporting hypothesis as

$\mathrm{H} 3_{0}: A I V \leq \operatorname{mean}\left(A I V_{E}\right)$. Alternative hypothesis, $\mathrm{H}_{\mathrm{A}_{\mathrm{A}}}: A I V \geq \operatorname{mean}\left(A I V_{E}\right)$ where AIV is the abnormal idiosyncratic volatility associated with a stock transaction of a senator, and mean $\left(A I V_{E}\right)$ is the mean abnormal idiosyncratic volatility related to the earnings announcement's periods, i.e., during the past year's quarterly announcements ending in the quarter when the stock transaction happened.

Next, we formulate a testable version of Hypothesis 3, where we aim to test whether politicians are in the first group of insiders. One can speculate that senators are not only informed, but they are generally among the first group of people trading on information. This can allow them to be the first to "buy the rumor, sell the news," and realize abnormal returns. To test this hypothesis, we modify the computation of the AIV described in Section 3.1 by shifting the fiveday event window. We define $A I V_{F}$ (first), where the five-day window includes the transaction date and the following four days. Similarly, we define $A I V_{L}$ (last), as the four days prior to the transaction and the transaction date. Relationships (and ordering) of the $A I V, A I V_{F}$ and $A I V_{L}$ can 
shed more light on whether and how quickly the senators receive and trade on the information. We therefore specify two additional tests for Hypothesis 3 as follows.

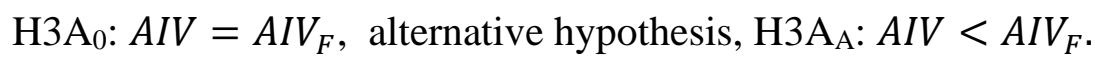

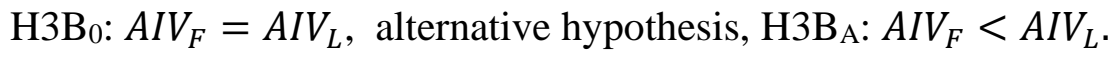

\section{Data and Descriptive Statistics}

We use data from the United States Senate Financial disclosures (https://efdsearch.senate.gov/), which started in 2012 following the STOCK Act. Senators have an option to either 1) report their transactions on a paper form that is then scanned and made available online or 2) fill it out electronically. They have 30 to 45 days to report each transaction and generally do this in batches, rather than individually. Since the paper reports are more difficult to track and analyze (handwritten, with instances of missing stock identification and dates), it is plausible that the amount of potentially informed trades is higher in paper transactions. Therefore, it is worth stressing that our analysis using the electronic records on senators' transactions provides a lower bound of the extent of the political insider trading.

From the electronically filed reports, we are able to identify the type of the investment, whether the asset was bought or sold, whose account was used for the trade, the range of dollar value of the transaction, and the security. The final dataset contains 8,509 total transactions, with 7,474 stocks, 68 non-public stocks, 41 stock options, 331 municipal securities, 298 corporate bonds, and 297 other securities (See Table 1 for detail breakdown). The electronic version of the reports covers transactions of 49 different senators, 22 Democrats and 27 Republicans. The average tenure is 11.5 years and $47 \%$ of these senators were members of the House previously.

Overall, there are 4,866 unique transactions (Senator-Date) of the 8,600 total transactions. This pattern can potentially be explained by senators trying to maintain a low profile while making 
informed trades with high abnormal returns and/or by obscuring the total amount invested. ${ }^{9}$ Additionally, the pattern casts further doubt on the appropriateness of portfolio and buy-and-hold analyses for revealing the extent of the insider trading.

Lastly, as part of the STOCK Act, records are only kept for 6 years after retirement. This means that if a senator retired before 2014, the records of his trades are no longer available. Our database is continually updated from January 2020 , meaning that we have data for any senator who did not quit before January 2014 and uses the electronic system for filing the stock transactions.

Table 1 depicts the distribution pattern of transactions by type of security and direction of the trade over the years, where Panel A shows the total number of trades and Panel B shows the percentage of the total transaction for the given type of security and direction of the trade. First, we observe that there are very few observations in 2012 and 2013. This is primarily because a lot of the early reports are not useable, and that several senators had retired, with their reports no longer available There is also a chance that the trading activity was lowered after the introduction of the STOCK Act, since politicians' trading activity was under higher scrutiny (e.g., Huang and Xuan, 2019), but this hypothesis is beyond the scope of this paper.

\section{--- Insert Table 1 around here ---}

The number of transactions is not very stable through the years. A possible explanation for the dip in transactions in 2016 could be the uncertainty about the presidential election and the power shift in the political landscape. A similar explanation may apply for the dip in 2019, when rising uncertainty led more traders to adjust their portfolios towards less risky assets, which is supported by the evidence that in 2019 we see the highest number of transactions in both municipal

\footnotetext{
${ }^{9}$ This reasoning is based on the insights from the model of Kyle (1985), where the large informed market maker uses the noise created by other traders to mask his trading activity and make an abnormal return.
} 
and corporate bonds. ${ }^{10}$ Another possible explanation is that many analysts were predicting a stock market crash and recession in 2019. This might have caused senators to become more reluctant to invest in the market, even if they had some inside information. Additionally, senators might be aware that taking advantage of high-profile situations, such as recession, might bring a higher level of scrutiny. This was confirmed when several senators sold all their stocks prior to COVID-19 lockdowns and were investigated by the ethics committee (Ziolkowski 2020).

As part of the STOCK Act, even a senator's immediate family needs to report their transactions following the same format. Our findings show that most transactions happen on Joint accounts, with Spousal accounts being second, Self-account third and Child account last. ${ }^{11}$ This result supports the findings by Karadas (2018), who suggested that senators' spouses might be trading based on insider information. While this may certainly be the case, it could also simply be a result of politicians using their spouses' accounts to conduct some of their trades, believing that doing so will allow them to keep a lower profile, as the spouses' trading history might not be followed closely.

Next, we can compare diluted versus non-diluted transactions. For a transaction to be classified as diluted one of two things must happen. Either the senator has made several transactions involving a given security in the same day, or he has traded the same security in immediately subsequent trading days. If either of those conditions are met, we classify all transactions in the given days as diluted transactions.

Our results show that almost $51 \%$ of stock transactions were diluted. On the one hand, this pattern could be consistent with politicians' use of the noise caused by uninformed traders to make

\footnotetext{
${ }^{10}$ Though it may be hard to take advantage of insider information in a stock market, since it requires more financial knowledge, it can be much easier in the bonds market. This may be why bonds are the second most traded category after stocks. This paper will not examine the issue more closely, but the problem warrants closer examination.

${ }^{11}$ Detailed decomposition of the transactions by account type is available in internet appendix.
} 
profit on their insider information without alerting the market (which is in line with the model of Kyle (1985), or with politicians' desire to mask the size of the total investment in order to make it harder for observers to calculate actual returns). On the other hand, this pattern of diluted transactions could simply be the result averaging down the cost.

We should note that there might be even more diluted transactions than we are registering. There might be transactions that are a day (or more) apart, but that were made with the same intentions in mind. However, extending the possible time window associated with defining diluted transactions raises the chance of increasing the noise in the data. Therefore, we restrict the time window to only consecutive trade days.

The pattern of the diluted trades over the years is not very clear. ${ }^{12}$ Their number is likely affected by political uncertainty and pushed by legislative activity, which provides a foundation for political inside information. For example, election years are characterized by a higher number of diluted trades compared to post election years. This suggests that the dilution could be correlated with potential insider trading because it serves as a tool to mask the trading activity. We examine these issues in more detail in Section 5.

\section{Results}

This section is structured as follows. First, in Section 5.1, we present the results associated with testing Hypothesis 1, i.e., analysis of the buy and hold returns of stocks traded by senators. Section 5.2 presents the results associated with testing Hypothesis 2, i.e., estimation and testing of the information asymmetry proxied by the AIV. Section 5.3 presents the results of tests of Hypotheses 3, 3A, and 3B, devoted to the research question if the senators are in the first group of the insiders

\footnotetext{
${ }^{12}$ Detailed decomposition of diluted transactions is available in the internet appendix.
} 
and comparison of information asymmetry around the politicians' trade and around earning announcements. Finally, Section 5.4 includes an analysis of the determinants of AIV and buy-andhold returns using auxiliary regressions.

\subsection{Results for analysis of the buy and hold stock returns following senator's trades}

We can now conduct t-tests and sign tests for our Hypothesis $1 \mathrm{~A}$ of whether stock returns outperform the market in each given year and for each holding period commencing with the day of a senator's trade. Table 2 reports the means of market-adjusted returns and their significance as well as the sign test ratios.

\section{--- Insert Table 2 around here ---}

Overall, Table 2 shows clear support for Hypothesis 1 that politicians' buy-and-hold returns outperform the market. With the exception of the shortest holding period, we reject the null hypothesis, i.e., we find support for the notion that senators' stock purchases outperform the market at $1 \%$ significance. This result is in contrast to the results of Eggers and Hainmueller (2014). However, we must keep in mind that they use data prior to the STOCK Act, but during a period of intense interest in senator transactions, i.e., after Ziobrowski et al. (2004) had documented the profitability of politicians' investments and caused increased scrutiny, but preSTOCK Act, after which the transactions reports were made public and could be audited. ${ }^{13}$

When we analyze the patterns of the excess market returns by year, we can still observe that in most cases the averages are positive and significant at the $1 \%$ level. However, there are a few negative and significant excess returns, which are present for some holding periods in 2015

\footnotetext{
${ }^{13}$ Also note that Eggers and Hainmueller (2014) admit as a possibility that prior to the STOCK Act senators could intentionally omit incriminating transactions in their reports.
} 
and 2018. Let us also note that in both 2015 and 2018, the largest portion of stocks were sold, and most transactions were diluted. ${ }^{14}$

Overall, the observed patterns of the abnormal market returns are amplified with the longer hold periods. This longevity suggests that value-relevant political information may take a while to become incorporated into stock prices. A nonparametric version of our test procedure, the sign test of (Snedecor \& Cochran 1989), confirms and magnifies the results of the $t$-tests.

As documented in Appendix 2, we examine industry-adjusted returns for stock purchases and confirm that our results are qualitatively consistent, although the $t$-test is not significant or positive for a large portion of the results. However, when coupled with the results of the sign tests, which are positive and significant for the majority of the sample, the lack of significance for the $t$ test could be explained by the high variation of the excess industry returns. Nevertheless, it is intuitive that, on average, outperforming the industry portfolio would be less common than outperforming the market, since corporate insider information is mostly available only to a limited number of senators who, for example, may sit on important committees and observe corporate lobbying activities (Hainmueller \& Eggers 2014).

\subsection{Results for Analysis of Abnormal Idiosyncratic Volatility}

In Sections 5.2 and 5.3 we aim to analyze if politicians' trades are also associated with periods of higher information asymmetry. Since such information asymmetry cannot be simply attributed to a few recorded politicians' transactions, high AIV values during periods around politicians' trades would imply that 1) many more people at Capitol Hill are relying on the same political inside

${ }^{14}$ This pattern seems to imply that senators' decisions to sell are less informative, perhaps because of bias, such as the disposition effect. Another potential explanation for the negative returns in 2015 and 2018 may be that senators were more focused on protecting their wealth when a regime shift in the upcoming election became more likely. This could be further supported by a different pattern for municipal and corporate bonds. 
information and/or 2) this valuable inside information could be leaked to other market participants. Accordingly, we test Hypothesis 2 by decomposition of factors that drive abnormal idiosyncratic volatility (AIV).

Table 3 below contains mean AIVs based on a 5-day window around the stock trade across years and different types of characteristics. For the sake of space, we report only the 5-day period results, but the complete set of results using alternative windows is available in the internet appendix.

\section{--- Insert Table 3 around here ---}

Table 3 presents means of the AIV computed across years, personal characteristics, and account types. Transactions conducted using accounts belonging to a senator's child do not carry significant AIV; the highest AIV is associated with the joint accounts (9.7\%), followed by spouseowned account $(-1.8 \%)$ and self-owned account $(-3.0 \%)$, with the child's account representing a very low value of the AIV (-12.5\%). These results suggest that politicians may refrain from using their own accounts when trading based on potential insider information and that use of a child's account is rather limited.

In terms of the direction of trade, we can observe that partial sales are associated with a higher AIV even when compared to purchases. This could, however, be caused by the lack of legislative activity in 2014, when the mean AIV for purchases was low (and negative). Moreover, unlike corporate insiders documented in Jeng et al. (2003), senators can use their insider information to minimize losses. For example, in early 2020, senators with access to information about the incoming measures against COVID-19 took their money out of the market (Ziolkowski 2020). 
The effect of diluted transactions could be more complex, namely because of a wider window and a higher noise associated with the diluted transactions. The results are very similar when we use a 7-day window for the calculation of $\mathrm{AIV}^{15}$, but with lower mean values, suggesting that increasing the time window not only prevents us from capturing more information asymmetry but also increases the noise in the measurement. In Section 5.4, we analyze factors affecting the AIV and potential channels of the information leak, using auxiliary regressions.

\subsection{Different measures of Abnormal Idiosyncratic Volatility}

In this section we define modified versions of the AIV to analyze if politicians are in the first wave of informed traders (Hypotheses 3A and 3B), and to compare the extent of the AIV associated with the politician's trade with the AIV connected with the quarterly earnings (Hypothesis 3), as defined by Yang et al. (2020). To test Hypothesis 3, we denote the quarterly earnings $A I V$ as $A I V_{E}$ (earnings). To test hypothesis $\mathrm{H} 3 \mathrm{~A}$ and $\mathrm{H} 3 \mathrm{~B}$ we define $A I V_{F}$ (first informed) and $A I V_{L}$ (last informed) using different event windows. Whereas the regular AIV takes two days before the trade and two after, including the trade day, $A I V_{F}$ takes the 4 days after the trade and the $A I V_{L}$ takes the 4 days before the trade day, both including the trade day.

The logic behind the tests included in this section is that if the politician's trades are truly in the first wave of informed trades, the $A I V_{F}$ will be the largest of the three measures, since the 5day window following their trade will contain most of the informed trades. Conversely, if the politician's trades are lagging behind those of other informed traders about a certain event the largest measure will be $A I V_{L}$.

\section{--- Insert Table 4 around here ---}

\footnotetext{
${ }^{15}$ Available in the internet appendix.
} 
In Table 4 we show the means of the $A I V, A I V_{F}, A I V_{L}$, and $A I V_{E}$ throughout the years. We see that the highest $A I V$ is associated with the regular definition of the $A I V$, followed by $A I V_{L}$ and then by $A I V_{F}$. This could suggest that senators are "in the middle of the pack" of the informed traders and are rarely the first ones to trade on the news. A potential explanation for this could be that if the information is caused by the legislative activity of politicians, the staffers and aids of politicians could trade on the rumor of the legislation being introduced, whereas the senators could trade when it is definitive. Or, alternatively, senators may deliberately try to avoid being the first ones to trade on political inside information in order to avoid scrutiny.

To formally test Hypothesis 3, we use both the $t$-test and the sign test, as in the previous section. We report the battery of tests in Table 5 .

\section{--- Insert Table 5 around here ---}

Table 5 presents the test of the differences between the average values of various AIV. It confirms that the "regular" AIV (i.e., the one from an estimation window defined symmetrically around the day of the trade) has the highest values, in support of the view that politicians are "in the middle of the pack" of the informed traders.

The observed differences across years could partly be due to different levels of legislative activity and/or change in the ruling party/administration. For example, 2014 saw the lowest level of legislative activity in the senate in our sample. This implies a lower amount of potential political inside information available to senators, which explains the negative mean values of the AIV in 2014. In 2017, the first year of the new Trump administration, information that could affect the market might have been driven mainly by the president himself, potentially leading to the observed negative values for AIV. 
Overall, we see that the AIV associated with politicians' trades is higher than that around earnings announcements $\left(A I V_{E}\right.$ as defined in Yang et al. (2020)), except for the years discussed before (2014 and 2017). This result implies that, on average, information asymmetry during periods around senator transactions is greater than during periods around quarterly earnings announcements. More importantly, this result supports our view that there is a flow of valuable private information from Capitol Hill and that senators' trading activity is only the tip of the iceberg. ${ }^{16}$ Furthermore, it raises a question regarding their choice of stocks to invest in. Our results imply that either the firms the senators invest in are more susceptible to legislative shocks or that there are value-relevant political information leaks, which the rest of the uninformed investors are unaware of.

Our analysis and results suggest that there is a need for further research to better understand the relationships between firms and politicians and to test whether firms are complicit and provide information to politicians. Note that in our paper we do not analyze transactions involving corporate bonds and municipal security transactions, where senators could also be exploiting political inside information to earn excess returns.

Finally, it is worth noting the actual AIV associated with earnings may be much larger than that presented in Yang et al. (2020), once the days during the transactions of senators are removed from the control sample. The information asymmetry linked to politicians' trading is quite sizeable and therefore, it could result in underestimating the magnitude of the insider trading around the other events like earning announcements.

\footnotetext{
${ }^{16}$ Most of the individuals who have access to the information do not have to report their investments. This only leaves using congressmen's and senators' investments as proxy for the investments in Capitol Hill (Kim 2012; Lawder \& Cowan 2012).
} 


\subsection{Determinants of politicians' stock performance and political information risk}

We estimate regression models of politicians' stock trade performance (buy-and-hold returns) and political information risk (AIV). Both models include an extensive list of standard control variables, but our focus is on political viariables (i.e., politicians personal and legislative characteristics) that may reveal what the possible channels are for the information asymmetry around senators' stock transacton dates.

Several variables are related to Senate legislative activity. The Legislative effectiveness score $(\mathrm{LES})^{17}$ measures how well the senator advances his agenda items through the legislative process and into law. A high LES score implies greater influence and better connections within the U.S. Senate (e.g., see (Fowler 2006a, b)) and therefore better informed. Senators also gather information from serving on committees with better access to important news (e.g. on the policy agenda in general, or specific pieces of legislation) and with the benefit of being able to observe relevant individual firm lobbying, which can give them further valuable insight (Hainmueller \& Eggers 2014). To capture this effect we include dummies for four important committees: 1) Finance, 2) Economic, 3) Energy and Natural Resources, and 4) Commerce, Science, and Transportation. To account for the importance of the current legislative events we include the Number of bills lobbied for and Number of lobbyists on the day of the transaction. For every transaction date we sum the number of bills that were introduced and had at least one lobbyist. Additionally, we sum the total amount of lobbyists across all bills introduced on the transaction date. Finally, there is some evidence that investments in local firms could result in higher returns (Hainmueller \& Eggers 2014). We therefore include the Home bias indicator variable that is equal to 1 when a senator's stock trade involves a firm from his/her home state, and 0 otherwise.

\footnotetext{
17 The methodology along with the data can be found at https://thelawmakers.org/
} 
As firm controls, we employed standard variables used in asset pricing models: Past profitability, Illiquidity, Firm size, Book-to-market ratio, and Beta. Past profitability is measured using four separate past stock returns, following Brennan et al. (2012). Similarly, we use a group of variables $R_{m-1}, R_{[m-3, m-2]}, R_{[m-6, m-4]}, R_{[m-12, m-6]}$, which stand for return over the last month, months 3 to 2,6 to 4 , and 12 to 6 , respectively. The several windows of returns are calculated in such a way as to avoid potential multicollinearity. Illiquidity is measured following Amihud (2002) as a sum of absolute values of daily returns divided by daily volume for the year, multiplied by $10^{\wedge} 6$. Firm size is the log of market value of equity. Book-to-market ratio is the $\log$ of the book-to-market ratio. Beta is calculated using the Fama-French (1993) 3-factor model over the past 6 months. However, Beta is only used as a control variable for the AIV regression. Summary statistics are available in the internet appendix.

In Table 6 we report results for three AIV regression specifications. Column (1) contains both tenure and age groups. In column (2) we omit the tenure and keep the age groups. This alternative specification serves as a sensitivity check since tenure and age are highly correlated. Finally, in column (3) we use a subsample that includes only stock purchases. This subsample result can serve as a better complement for the results we present in the next table (market-adjusted returns analysis).

\section{--- Insert Table 6 around here ---}

Table 6 reveals some interesting results. Senator tenure and age are the only personal characteristics that remain statistically significant when we include the other control variables. Specifically, early career and mid-career senators' trades generate significantly higher informed trading than those of late-career senators. The magnitudes are economically meaningful. More 
specifically, compared to senators with a long tenure (14-35 years), those whose tenure is short (04 years) present, a 12.2 percentage points higher AIV, on average.

The Number of bills coefficient is positive and significant, suggesting that higher levels of overall legislative activity generate more insider information, which in turn increases information asymmetry. The Finance variable's coefficient is also positive and significant. This indicates that trades by finance committees' members are significantly more informative than the rest, suggesting that such a committee is privy to a substantial amount of value-relevant information. In addition, no other committee membership appears to be a determinant of AIV, with the exception of energy committee membership, which has a positive effect in the model (3) (i.e., using the subsample of stock purchases).

The observed negative Home bias effect may appear surprising at first glance. However, this effect may simply imply that senators may be reluctant to widely share insider information about firms located in their home state. As mentioned previously, the AIV captures the abnormal stock activity resulting in departures from the Fama-French asset pricing model. Therefore, changes in AIV cannot be merely caused by a few reported trades, but rather require substantial additional trading activity behind it. Hence, when inside information is available to a limited number of market participants, we would not be able to detect information asymmetry. Alternatively, the negative coefficient of Home bias may also indicate that senators deliberately avoid trading on insider information about home state firms. The picture will become clearer further below when we complement this result with the corresponding one from the next table.

Lastly, we see that the Number of lobbyists has a negative and significant effect on AIV, which is consistent with the view that the lobbyists reduce information risk by disseminating valuerelevant information to the market. In sum, information risk around senator stock trade dates 
appears to increase with the senatorial activity (Number of bills) and decrease with lobbying activity (Number of lobbyists).

Note that by construction, stocks with many politicians' trades over the past year would have a lower number of the NAT days. This feature could potentially distort the value of AIV and hence consequently effect the results. To account for this data specific aspect and to test the robustness of our results, we also run a weighted OLS regression, where we use the ratio of NAT days to ATT days as weights. The results are similar to in the main specification, showing that our results are not biased by a larger number of ATT days. In the interest of space, the detailed results are not presented here; they are available in the internet appendix.

Now we will analyze the abnormal market returns to determine the main drivers of individual profitability for the different stock purchases.

\section{--- Insert Table 7 around here ---}

Table 7 depicts results of the market-adjusted buy-and-hold returns analysis. Interestingly, stocks bought by early- or mid-career senators have lower (higher) market-adjusted returns over shorter (longer) holding periods. We can also see that contrary to the AIV regressions, age is not as significant a predictor, with the exception of the 51-60 category that seems to be producing an abnormal performance, albeit only in the short run, being significant for more than one holding period. We also observe that diluted trades do not yield higher returns, but as mentioned before, this result might be caused by the noise associated with the variable's measurement.

We can also see that the Legislative effectiveness score $(L E S)$ coefficient is negative for the short holding period models but turns positive and significant for the longer period (two- and three-month holding period) models. This might suggest that senators who are better connected within the legislative network may possess information that takes at least two months to be 
incorporated in market prices. We also see that home state stocks bought by senators also perform significantly better over longer holding periods, which supports the findings of Hainmueller and Eggers (2014). Coupled with the fact that the trades of home state stocks are associated with lower AIV (across all three model specifications in Table 6), this result suggests that senators seem to possess value-relevant information about home state firms, but they are not sharing it with many others. Lastly, a rather puzzling result involves stocks purchased by Economic committee members, which perform significantly worse than the rest across all holding periods. It is, however, important to note that buy-and-hold returns can be very different from the real returns, and even those might be very different from the returns a proficient investor would have with the same information.

Overall, our buy-and-hold returns analysis nicely complements the AIV regressions' findings. Our results show that senators' stock trading activity reported in electronic filings is information driven. Nevertheless, the politically informed trading we uncover could be only the tip of the iceberg, since there are a lot more people who have access to the same information but do not have to file their trades. In addition, many senators choose to file their transactions on paper, which makes them even more difficult to analyze. ${ }^{18}$

\section{Sale Transactions}

We do not analyze stock sale transactions in this paper. This is because while purchases are a clear signal of a positive view on the stock, sales trades include a much more complex and diverse set of possible motivations. For example, the decision to sell could not only be driven by negative information, but more commonly by liquidity needs or by the decision to secure a profit or

\footnotetext{
18 This potentially larger problem warrants more examination in a future study.
} 
minimize a loss. Moreover, the timing of a sale can be distorted by decision bias like the disposition effect.

The STOCK Act does not require senators to report the exact amount that was invested or the price at which they purchased (and sold) the security, which makes it impossible to accurately calculate realized returns on their investments. This, in turn, makes it very hard to thoroughly disentangle the different motives for selling. As a result, even though there are documented cases of senators' informed selling aimed at protecting their investments (e.g., selling their stocks before the incoming measures against COVID-19 (Ziolkowski 2020), a proper identification of such a subsample of sales transactions remains elusive given the current data. Therefore, the analysis of sale transactions needs to be performed separately and using different methods, since neither buyand-hold of stocks after senators sell them nor a portfolio analysis after selling by senators (as reported by C. Eggers and Hainmueller (2013)) can distinguish between sales motivated by insider information, disposition effect, need for liquidity, or other motivations.

In Appendix 3, we include a robustness test of politicians' stock trade performance based on a measure that relies on the premise that the average sale should be less informed than the average purchase trade. We match every purchase transaction with the most recent sale transaction by the same politician that occurred within a week of the purchase. We then subtract the return of the stock the senator sold with the return of stock they just purchased (if they sold multiple stocks on the same day we take their average return) and compute the difference of the market-adjusted returns. The results of t-tests show that returns are higher after the purchases and the effect only increases with the longer holding periods. These results suggest that selling may often be motivated by reasons other than negative information. A more rigorous analysis of sales trades is left for future research. 


\section{Conclusion}

This paper analyzes electronic filings of stock trades made by senators in compliance with the STOCK Act, in order to test whether politicians and their networks (i.e., staff, lobbyists, otherhome state- legislators, and others) use political insider information in their investment decisions. We confirm politically informed trading by employing a buy-and-hold return analysis for stocks purchased by senators, a departure from the synthetic portfolio analysis used in prior studies. Moreover, we propose a modification of the abnormal idiosyncratic volatility (AIV), first introduced by (Yang et al. 2020), to measure the extent of information risk associated with periods around politicians' trades. Application of this approach allows us to capture possible (mis)use of political inside information for a much broader set of political actors, who may possess the same information as the senators in our sample but are not required to file reports on their stock trades.

We show that information asymmetry associated with stocks traded by senators is on average quite high (3.6\%) and driven by the senator's access to important legislative information acquired by being an effective legislator or member of an important committee. Our analysis confirms that information risk is elevated (attenuated) on days when there is a lot of legislative (lobbyist) activity. Lastly, we show that investing in the stock of a company headquartered in the senator's state can yield very high and significant returns, especially for longer holding periods, confirming the findings of Hainmueller and Eggers (2014). Moreover, these trades are associated with significantly lower levels of AIV, suggesting that perhaps senators refrain from sharing valuerelevant information with a wider set of associates.

Overall, our results showing the high AIV around politicians' trades support the view that senators' use of political inside information represents only the tip of the iceberg. There are many 
more legislators, politicians, and selected market participants who have access to the same information but do not have to file their returns. We also believe that our results could shed more light on the puzzle of observed negative AIV values associated with some earning announcements (Yang et al. 2020). Our results suggest that a cleaner measure of AIV around corporate information events such as earnings announcements could be obtained after purging periods surrounding politicians' trades. Finally, our evidence suggests that there needs to be further discussion and deliberation leading to legislation aimed at strengthening the STOCK Act. 


\section{References}

Aktas, N., De Bodt, E., Van Oppens, H., 2008. Legal insider trading and market efficiency. Journal of Banking \& Finance 32, 1379-1392

Ali, U., Hirshleifer, D., 2017. Opportunism as a firm and managerial trait: Predicting insider trading profits and misconduct. Journal of Financial Economics 126, 490-515

Amihud, Y., 2002. Illiquidity and stock returns: cross-section and time-series effects. Journal of financial markets 5, 31-56

Back, K., Collin-Dufresne, P., Fos, V., Li, T., Ljungqvist, A., 2018. Activism, strategic trading, and liquidity. Econometrica 86, 1431-1463

Bamber, L.S., Barron, O.E., Stevens, D.E., 2010. Trading volume around earnings announcements and other financial reports: Theory, research design, empirical evidence, and directions for future research. Research Design, Empirical Evidence, and Directions for Future Research (February 27, 2010)

Belmont, W., Sacerdote, B., Van Hoek, I., 2020. Relief Rally: Senators As Feckless As the Rest of Us at Stock Picking. National Bureau of Economic Research

Boller, G., Ward, J., 1995. Taking Stock in Congress. by Joy Ward), Mother Jones, September/October Issue

Brennan, M.J., Chordia, T., Subrahmanyam, A., Tong, Q., 2012. Sell-order liquidity and the cross-section of expected stock returns. Journal of Financial Economics 105, 523-541

Brennan, M.J., Subrahmanyam, A., 1996. Market microstructure and asset pricing: On the compensation for illiquidity in stock returns. Journal of financial economics 41, 441-464

C. Eggers, A., Hainmueller, J., 2013. Capitol Losses: The Mediocre Performance of Congressional Stock Portfolios. The Journal of Politics 75, 535-551

Collin-Dufresne, P., Fos, V., 2015. Do prices reveal the presence of informed trading? The Journal of Finance 70, 1555-1582

Duchin, R., Sosyura, D., 2012. The politics of government investment. Journal of Financial Economics 106, 24-48

Easley, D., O'hara, M., 1987. Price, trade size, and information in securities markets. Journal of Financial economics 19, 69-90

Easley, D., O'hara, M., Saar, G., 2001. How stock splits affect trading: A microstructure approach. Journal of Financial and Quantitative Analysis, 25-51

Eggers, A.C., Hainmueller, J., 2014. Political capital: Corporate connections and stock investments in the US congress, 2004-2008. Quarterly Journal of Political Science, 201226

Fama, E.F., French, K.R., 1993. Common risk factors in the returns on stocks and bonds. Journal of

Fowler, J.H., 2006a. Connecting the Congress: A study of cosponsorship networks. Political Analysis, 456-487

Fowler, J.H., 2006b. Legislative cosponsorship networks in the US House and Senate. Social Networks 28, 454-465

Hainmueller, J., Eggers, A.C., 2014. Political Capital: Corporate Connections and Stock Investments in the U.S. Congress, 2004-2008. Quarterly Journal of Political Science 9, 169-202

Hasbrouck, J., 1991. Measuring the information content of stock trades. The Journal of Finance 46, 179-207 
Hassan, T.A., Hollander, S., Van Lent, L., Tahoun, A., 2019. Firm-level political risk: Measurement and effects. The Quarterly Journal of Economics 134, 2135-2202

Huang, R., Xuan, Y., 2019. 'Trading'Political Favors: Evidence from the Impact of the STOCK Act. Available at SSRN 2765876

Jeng, L.A., Metrick, A., Zeckhauser, R., 2003. Estimating the returns to insider trading: A performance-evaluation perspective. Review of Economics and Statistics 85, 453-471

Karadas, S., 2018. Family ties and informed trading: evidence from Capitol Hill. Journal of Economics and Finance 42, 211-248

Kim, O., Verrecchia, R.E., 1997. Pre-announcement and event-period private information. Journal of accounting and economics 24, 395-419

Kim, S.H., 2012. The last temptation of Congress: Legislator insider trading and the fiduciary norm against corruption. Cornell L. Rev. 98, 845

Kim, S.H., 2013a. Insider trading as private corruption. UCLA L. Rev. 61, 928

Kim, S.H., 2013b. What governmental insider trading teaches us about corporate insider trading. In: Research handbook on insider trading. Edward Elgar Publishing.

Krinsky, I., Lee, J., 1996. Earnings announcements and the components of the bid-ask spread. The Journal of Finance 51, 1523-1535

Kyle, A.S., 1985. Continuous auctions and insider trading. Econometrica: Journal of the Econometric Society, 1315-1335

Lawder, D., Cowan, R., 2012. Congress Quietly Repeals Plan for Internet Financial Disclosures. In: Reuters. Thomson Reuters, https://www.reuters.com/article/net-us-usa-congresssecurity-idUSBRE93B0ZJ20130412

Odean, T., 1999. Do investors trade too much? American economic review 89, 1279-1298

Snedecor, G.W., Cochran, W.G., 1989. Statistical methods, 8thEdn. Ames: Iowa State Univ. Press Iowa 54, 71-82

Tahoun, A., 2014. The role of stock ownership by US members of Congress on the market for political favors. Journal of Financial Economics 111, 86-110

Vega, C., 2006. Stock price reaction to public and private information. Journal of Financial Economics 82, 103-133

Yang, Y.C., Zhang, B., Zhang, C., 2020. Is information risk priced? Evidence from abnormal idiosyncratic volatility. Journal of Financial Economics 135, 528-554

Ziobrowski, A.J., Cheng, P., Boyd, J.W., Ziobrowski, B.J., 2004. Abnormal returns from the common stock investments of the US Senate. Journal of financial and quantitative analysis 39, 661-676

Ziolkowski, C., 2020. Senators dumped stocks amid the coronavirus crisis. Here's what we know about Congress and financial self-interest. In: Washington Post. Washington Post, New York 
Table 1. Distribution of senators' trades by security type and year

Panel A. Total number of trades

\begin{tabular}{|c|c|c|c|c|c|c|c|c|c|c|}
\hline \multirow{2}{*}{ Type of transaction/security } & \multirow{2}{*}{$\begin{array}{l}\text { Direction of } \\
\text { trade }\end{array}$} & \multicolumn{9}{|c|}{ Year of the recorded transaction } \\
\hline & & 2012 & 2013 & 2014 & 2015 & 2016 & 2017 & 2018 & 2019 & Total \\
\hline \multirow[t]{2}{*}{ Stock } & Buy & 2 & 5 & 424 & 752 & 631 & 723 & 745 & 323 & 3,794 \\
\hline & Sale & 0 & 1 & 475 & 821 & 481 & 581 & 697 & 431 & 3,680 \\
\hline \multirow[t]{2}{*}{ Corporate bond } & Buy & 0 & 1 & 34 & 23 & 27 & 16 & 32 & 36 & 175 \\
\hline & Sale & 0 & 0 & 35 & 27 & 11 & 14 & 15 & 17 & 123 \\
\hline \multirow[t]{2}{*}{ Municipal security } & Buy & 1 & 7 & 14 & 33 & 29 & 32 & 27 & 114 & 269 \\
\hline & Sale & 2 & 4 & 6 & 5 & 10 & 22 & 7 & 6 & 62 \\
\hline \multirow[t]{2}{*}{ Non-public stock } & Buy & 0 & 0 & 3 & 5 & 8 & 8 & 8 & 7 & 40 \\
\hline & Sale & 0 & 0 & 1 & 4 & 1 & 11 & 6 & 5 & 28 \\
\hline \multirow[t]{2}{*}{ Stock option put } & Buy & 0 & 0 & 0 & 0 & 4 & 2 & 0 & 0 & 6 \\
\hline & Sale & 0 & 0 & 1 & 0 & 2 & 0 & 0 & 0 & 35 \\
\hline \multirow[t]{2}{*}{ Other securities } & Buy & 0 & 0 & 13 & 9 & 34 & 40 & 75 & 11 & 191 \\
\hline & Sale & 0 & 1 & 7 & 10 & 1 & 23 & 52 & 9 & 106 \\
\hline \multirow[t]{2}{*}{ Total } & Buy & 3 & 13 & 488 & 822 & 733 & 821 & 887 & 491 & 4,475 \\
\hline & Sale & 2 & 6 & 525 & 867 & 506 & 651 & 777 & 468 & 4,034 \\
\hline
\end{tabular}

Panel A reports the total amounts of transactions by year and security type, with the last column and row reporting the total by security type and year, respectively. 
Panel B. Senators' trades by security type: Percentage distribution by year (row percentages)

\begin{tabular}{|c|c|c|c|c|c|c|c|c|c|c|}
\hline \multirow[b]{2}{*}{ Type of transaction/security } & \multirow{2}{*}{$\begin{array}{l}\text { Direction of } \\
\text { trade }\end{array}$} & \multicolumn{9}{|c|}{ Year of the recorded transaction } \\
\hline & & 2012 & 2013 & 2014 & 2015 & 2016 & 2017 & 2018 & 2019 & $\begin{array}{r}\text { Total } \\
(100 \%)\end{array}$ \\
\hline \multirow[t]{2}{*}{ Stock } & Buy & $0.1 \%$ & $0.1 \%$ & $11.2 \%$ & $19.8 \%$ & $16.6 \%$ & $19.1 \%$ & $19.6 \%$ & $8.5 \%$ & 3,794 \\
\hline & Sale & $0.0 \%$ & $0.0 \%$ & $12.9 \%$ & $22.3 \%$ & $13.1 \%$ & $15.8 \%$ & $18.9 \%$ & $11.7 \%$ & 3,680 \\
\hline \multirow[t]{2}{*}{ Corporate bond } & Buy & $0.0 \%$ & $0.6 \%$ & $19.4 \%$ & $13.1 \%$ & $15.4 \%$ & $9.1 \%$ & $18.3 \%$ & $20.6 \%$ & 175 \\
\hline & Sale & $0.0 \%$ & $0.0 \%$ & $28.5 \%$ & $22.0 \%$ & $8.9 \%$ & $11.4 \%$ & $12.2 \%$ & $13.8 \%$ & 123 \\
\hline \multirow[t]{2}{*}{ Municipal security } & Buy & $0.4 \%$ & $2.6 \%$ & $5.2 \%$ & $12.3 \%$ & $10.8 \%$ & $11.9 \%$ & $10.0 \%$ & $42.4 \%$ & 269 \\
\hline & Sale & $3.2 \%$ & $6.5 \%$ & $9.7 \%$ & $8.1 \%$ & $16.1 \%$ & $35.5 \%$ & $11.3 \%$ & $9.7 \%$ & 62 \\
\hline \multirow[t]{2}{*}{ Non-public stock } & Buy & $0.0 \%$ & $0.0 \%$ & $7.5 \%$ & $12.5 \%$ & $20.0 \%$ & $20.0 \%$ & $20.0 \%$ & $17.5 \%$ & 40 \\
\hline & Sale & $0.0 \%$ & $0.0 \%$ & $3.6 \%$ & $14.3 \%$ & $3.6 \%$ & $39.3 \%$ & $21.4 \%$ & $17.9 \%$ & 28 \\
\hline \multirow[t]{2}{*}{ Stock option put } & Buy & $0.0 \%$ & $0.0 \%$ & $0.0 \%$ & $0.0 \%$ & $66.7 \%$ & $33.3 \%$ & $0.0 \%$ & $0.0 \%$ & 6 \\
\hline & Sale & $0.0 \%$ & $0.0 \%$ & $2.9 \%$ & $0.0 \%$ & $5.7 \%$ & $0.0 \%$ & $0.0 \%$ & $0.0 \%$ & 35 \\
\hline \multirow[t]{2}{*}{ Other securities } & Buy & $0.0 \%$ & $0.0 \%$ & $6.8 \%$ & $4.7 \%$ & $17.8 \%$ & $20.9 \%$ & $39.3 \%$ & $5.8 \%$ & 191 \\
\hline & Sale & $0.0 \%$ & $0.9 \%$ & $6.6 \%$ & $9.4 \%$ & $0.9 \%$ & $21.7 \%$ & $49.1 \%$ & $8.5 \%$ & 106 \\
\hline \multirow[t]{2}{*}{ Total } & Buy & $0.1 \%$ & $0.3 \%$ & $10.9 \%$ & $18.4 \%$ & $16.4 \%$ & $18.3 \%$ & $19.8 \%$ & $11.0 \%$ & 4,475 \\
\hline & Sale & $0.0 \%$ & $0.1 \%$ & $13.0 \%$ & $21.5 \%$ & $12.5 \%$ & $16.1 \%$ & $19.3 \%$ & $11.6 \%$ & 4,034 \\
\hline
\end{tabular}

Panel B reports the distribution of each security and direction of trade by year (row percentages). The last column contains the total number of transactions over the entire period and represents a hundred percent base for scaling. 
Table 2. Results of tests for abnormal market returns of senators (Buy and Hold over selected periods)

\begin{tabular}{|c|c|c|c|c|c|c|c|c|}
\hline \multirow{2}{*}{ Hold period } & \multirow{2}{*}{ Statistical test } & \multicolumn{6}{|c|}{ Year of the recorded transaction } & \multirow{2}{*}{ Overall } \\
\hline & & 2014 & 2015 & 2016 & 2017 & 2018 & 2019 & \\
\hline \multirow[t]{2}{*}{ One week } & $t$-test & $0.008^{* * *}$ & $0.004^{*}$ & 0.003 & 0.001 & $-0.010^{* * *}$ & 0.005 & 0.001 \\
\hline & Sign test & $1.350^{* * * *}$ & $1.322^{* * *}$ & $1.283^{* * *}$ & $1.243^{* * *}$ & $0.690^{* * * *}$ & 1.171 & $1.129^{* * * *}$ \\
\hline \multirow[t]{2}{*}{ Two weeks } & $t$-test & $0.007^{* * *}$ & $-0.005^{*}$ & $0.018^{* * *}$ & $0.009^{* * *}$ & -0.005 & $0.013^{* * *}$ & $0.005^{* * *}$ \\
\hline & Sign test & $1.379^{* * *}$ & 0.968 & $1.760^{* * *}$ & $1.385^{* * *}$ & 1.023 & $1.733^{* * *}$ & $1.276^{* * *}$ \\
\hline \multirow[t]{2}{*}{ One month } & $t$-test & $0.017^{* * *}$ & $-0.015^{* * *}$ & $0.048^{* * *}$ & $0.022^{* * *}$ & $-0.015^{* * *}$ & $0.029^{* * *}$ & $0.011^{* * *}$ \\
\hline & Sign test & $1.755^{* * *}$ & 0.937 & $2.412^{* * *}$ & $1.692^{* * *}$ & $0.763^{* * *}$ & $2.082^{* * *}$ & $1.358^{* * *}$ \\
\hline \multirow[t]{2}{*}{ Two months } & $t$-test & $0.037^{* * *}$ & $-0.03^{* * *}$ & $0.095^{* * *}$ & $0.037^{* * *}$ & -0.009 & $0.047^{* * *}$ & $0.024^{* * *}$ \\
\hline & Sign test & $1.796^{* * *}$ & $0.765^{* * *}$ & $3.852^{* * *}$ & $1.838^{* * *}$ & $0.947^{* * *}$ & $2.471^{* * *}$ & $1.490^{* * *}$ \\
\hline \multirow[t]{2}{*}{ Three months } & $t$-test & $0.051^{* * *}$ & 0.005 & $0.121^{* * *}$ & $0.056^{* * *}$ & $0.013^{*}$ & $0.077^{* * *}$ & $0.049^{* * * *}$ \\
\hline & Sign test & $2.040^{* * *}$ & $1.258^{* * *}$ & $5.273^{* * *}$ & $2.081^{* * *}$ & $1.339^{* * *}$ & $2.149^{* * * *}$ & $1.929^{* * *}$ \\
\hline Number of observations & & 383 & 736 & 621 & 681 & 697 & 211 & 3,336 \\
\hline
\end{tabular}

This table reports the results of a test for abnormal market returns following senators' stock trades for 5 different holding periods-from one week to three months. Abnormal market return is defined as the difference between stock return and S\&P500 index return. For each holding period the first row contains the results of the pairwise t-tests of the hypothesis that the mean is equal to zero, while the second row contains the results of the sign test (also known as the median test),. For the sake of space, the sign test statistics recorded here are the ratio of positive/negative returns, along with the significance of the relevant test. This means that positive and significant values of the t-test and values greater than one for the sign test support the hypothesis of positive excess returns. The first two years (2012 and 2013) have very few observations and therefore the results for these years are not presented. The number of observations is related to the longest buy-andhold period, i.e., the number of observations for three months. It also represents the minimum number of observations across all holding periods. Since our stock returns data ends on December 31,2019, there is a lower number of observations in 2019. ${ }^{* * *},{ }^{* *}$, and ${ }^{*}$ denote statistical significance at $1 \%, 5 \%$ and $10 \%$, respectively. 
Table 3. Descriptive Statistics for the Mean of the Abnormal Idiosyncratic Volatility (AIV)

\begin{tabular}{|c|c|c|c|c|c|c|c|}
\hline \multirow{2}{*}{ Characteristics } & \multicolumn{6}{|c|}{ Year of the recorded transaction } & \multirow{2}{*}{ Total mean } \\
\hline & 2014 & 2015 & 2016 & 2017 & 2018 & 2019 & \\
\hline Child & $-14.5 \%$ & $-7.6 \%$ & $-6.8 \%$ & $-32.9 \%$ & $11.3 \%$ & $-5.9 \%$ & $-12.5 \%$ \\
\hline Joint & $-8.7 \%$ & $9.2 \%$ & $21.2 \%$ & $1.2 \%$ & $14.2 \%$ & $4.6 \%$ & $9.7 \%$ \\
\hline Self & $-12.9 \%$ & $-0.5 \%$ & $-4.1 \%$ & $-10.7 \%$ & $9.5 \%$ & $4.6 \%$ & $-3.0 \%$ \\
\hline Spouse & $-12.9 \%$ & $1.6 \%$ & $6.1 \%$ & $-7.3 \%$ & $7.2 \%$ & $-5.2 \%$ & $-1.8 \%$ \\
\hline Purchase & $-19.5 \%$ & $9.7 \%$ & $6.9 \%$ & $-7.4 \%$ & $12.3 \%$ & $7.6 \%$ & $2.9 \%$ \\
\hline Sale (Full) & $-9.7 \%$ & $-2.1 \%$ & $4.4 \%$ & $-7.8 \%$ & $5.4 \%$ & $-3.0 \%$ & $-2.9 \%$ \\
\hline Sale (Partial) & $-0.2 \%$ & $8.6 \%$ & $29.1 \%$ & $7.5 \%$ & $10.3 \%$ & $0.7 \%$ & $10.3 \%$ \\
\hline Age $41-50$ & $-36.5 \%$ & $0.2 \%$ & $20.1 \%$ & $-16.2 \%$ & $-35.9 \%$ & $20.4 \%$ & $-18.9 \%$ \\
\hline Age 51-60 & $-9.1 \%$ & $-3.5 \%$ & $2.4 \%$ & $-7.9 \%$ & $-4.6 \%$ & $-13.1 \%$ & $-5.0 \%$ \\
\hline Age $61-65$ & $-13.0 \%$ & $-18.1 \%$ & $2.9 \%$ & $-10.4 \%$ & $4.0 \%$ & $5.7 \%$ & $-3.3 \%$ \\
\hline Age $>65$ & $-17.6 \%$ & $11.5 \%$ & $18.2 \%$ & $-2.6 \%$ & $15.6 \%$ & $2.3 \%$ & $8.3 \%$ \\
\hline Non-diluted transactions & $-11.6 \%$ & $-0.1 \%$ & $8.6 \%$ & $-3.4 \%$ & $11.6 \%$ & $3.6 \%$ & $1.9 \%$ \\
\hline Diluted transactions & $-12.9 \%$ & $10.2 \%$ & $15.0 \%$ & $-6.0 \%$ & $9.5 \%$ & $0.7 \%$ & $5.1 \%$ \\
\hline Year mean & $-12.4 \%$ & $6.8 \%$ & $12.6 \%$ & $-4.3 \%$ & $10.4 \%$ & $2.7 \%$ & $3.6 \%$ \\
\hline Number of observations & 842 & 1,500 & 1,075 & 1,237 & 1,352 & 696 & 6,710 \\
\hline
\end{tabular}

This table reports the mean Abnormal Idiosyncratic Volatility (AIV) computed over the five-day window for different subsamples based on account type, transaction type, age group, diluted transactions and by year. AIV corresponds to the standard definition of the AIV associated with the politicians' transactions, i.e., using equations (1)-(4), which excludes five days around the senators' transactions. (i.e., two days before, trading day and two days after the transaction). A transaction is categorized as diluted if multiple transactions occur by the same senator for the same stock on the same day or on subsequent days.

Note: 2012 and 2013 have very few observations and therefore the results for these years are not presented 
Table 4. Mean of different measures of the AIV by year

\begin{tabular}{|c|c|c|c|c|c|c|c|}
\hline Variable & 2014 & 2015 & 2016 & 2017 & 2018 & 2019 & Total mean \\
\hline$A I V$ & $-12.4 \%$ & $6.8 \%$ & $12.6 \%$ & $-4.3 \%$ & $10.4 \%$ & $2.7 \%$ & $3.6 \%$ \\
\hline$A I V_{F}$ & $-14.4 \%$ & $1.5 \%$ & $8.9 \%$ & $-8.2 \%$ & $6.0 \%$ & $-2.7 \%$ & $-0.6 \%$ \\
\hline$A I V_{L}$ & $-6.7 \%$ & $6.8 \%$ & $7.5 \%$ & $-5.4 \%$ & $5.9 \%$ & $2.6 \%$ & $2.4 \%$ \\
\hline$A I V_{E}$ & $-1.4 \%$ & $-3.2 \%$ & $3.8 \%$ & $-3.9 \%$ & $0.7 \%$ & $-2.5 \%$ & $-1.0 \%$ \\
\hline Observations & 841 & 1,521 & 1,082 & 1,232 & 1,352 & 693 & 6,728 \\
\hline
\end{tabular}

This table contains the mean of different measures of Abnormal Idiosyncratic Volatility (AIV), computed over the five-day window. AIV corresponds to the standard definition of the AIV associated with the politician's transactions, i.e., using equations (1)-(4), which excludes five days around the senators' transactions. (i.e., two days before, trading day and two days after the transaction). The first informed trade $A I V_{F}$ and the last trade $A I V_{L}$ use that approach but the window is formed by the trading day and four days after, and four days before and trading day, respectively. The Earning Announcement $A I V_{E}$ is computed around the company announcement days, following the methodology of Yang et al. (2020). The first two years (2012 and 2013) have very few observations and as a result have been omitted. ${ }^{* * *},{ }^{* *}$, and ${ }^{*}$ denote statistical significance at $1 \%, 5 \%$ and $10 \%$, respectively. 
Table 5. Results of (pairwise) tests of differences between the various AIV.

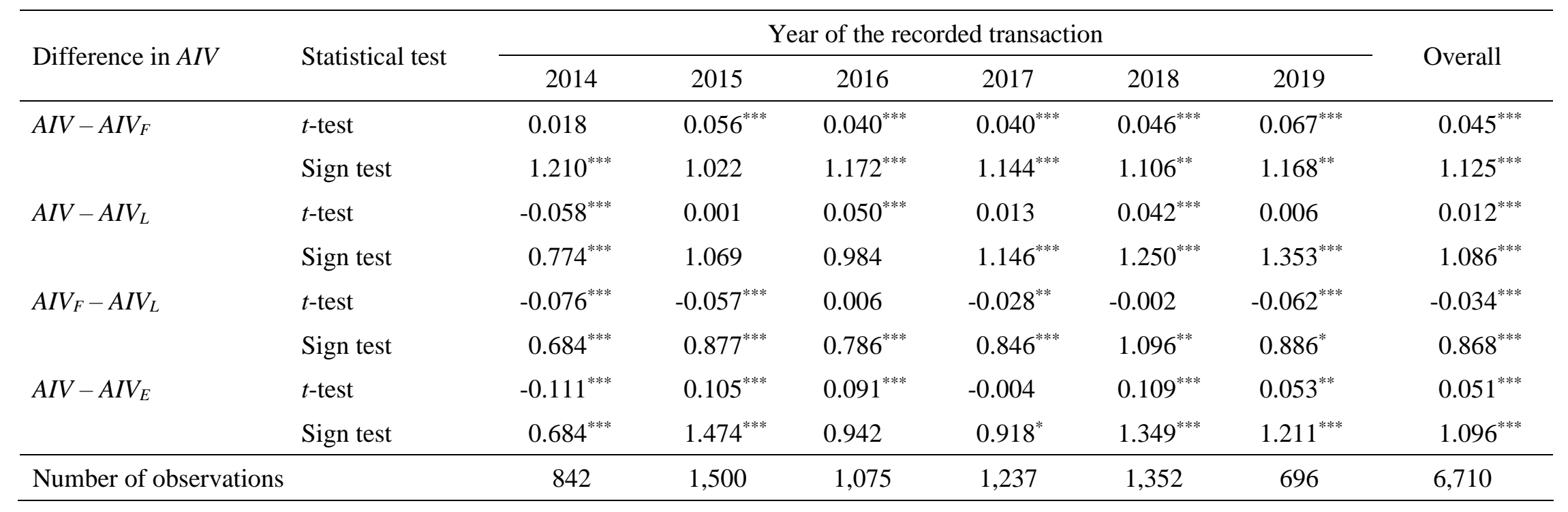

This table shows the results of different measures of Abnormal Idiosyncratic Volatility (AIV), computed over the five-day window. For each pair the first row contains the results of the pairwise t-tests, while the second row contains the results of the sign test (also known as the median test), testing the hypothesis that the difference is equal to zero. For the sake of space, the sign test statistics recorded here are the ratio of positive/negative differences in the AIV, with the significance of the relevant test. This means that positive values of the t-test and values greater than one for the sign test support the hypothesis of positive difference in the analyzed pairs of the AIV. Regular AIV corresponds to the standard definition of the AIV associated with the politicians' transactions, i.e., using equations (1)(4), which excludes five days around the senators' transactions. (i.e., two days before, trading day and two days after the transaction). The first informed trade $A I V_{F}$ and the last trade $A I V_{L}$ use that approach but the window is formed by the trading day and four days after, and four days before and trading day, respectively. Earning Announcement $A I V_{E}$ is computed around the company announcement days, following the methodology of Yang et al. (2020). The first two years (2012 and 2013) have very few observations and as a result have been omitted. ${ }^{* * *},{ }^{* *}$, and ${ }^{*}$ denote statistical significance at $1 \%, 5 \%$ and $10 \%$, respectively. 
Table 6. Decomposition of the AIV

\begin{tabular}{|c|c|c|c|}
\hline & \multicolumn{3}{|c|}{ Dependent variable $=$ AIV } \\
\hline & $(1)$ & $(2)$ & (3) \\
\hline & All transactions & All transactions & Purchases \\
\hline \multicolumn{4}{|l|}{ Senator tenure ${ }^{+}$} \\
\hline \multirow[t]{2}{*}{ Tenure $0-4$} & $0.122^{* * * *}$ & & 0.024 \\
\hline & $(0.031)$ & & $(0.042)$ \\
\hline \multirow[t]{2}{*}{ Tenure 5-13 } & $0.078^{* *}$ & & $0.099^{*}$ \\
\hline & $(0.039)$ & & $(0.054)$ \\
\hline \multicolumn{4}{|l|}{ Age category $^{++}$} \\
\hline \multirow[t]{2}{*}{ Age 41-50 } & $-0.227^{* * *}$ & $-0.225^{\text {*** }}$ & $-0.169^{*}$ \\
\hline & $(0.087)$ & $(0.084)$ & $(0.095)$ \\
\hline \multirow[t]{2}{*}{ Age $51-60$} & $-0.102^{* * *}$ & $-0.068^{* * *}$ & $-0.118^{* *}$ \\
\hline & $(0.036)$ & $(0.026)$ & $(0.059)$ \\
\hline \multirow[t]{2}{*}{ Age $60-65$} & $-0.075^{* *}$ & $-0.042^{*}$ & -0.041 \\
\hline & $(0.031)$ & $(0.025)$ & $(0.046)$ \\
\hline \multicolumn{4}{|l|}{ Account type $e^{+++}$} \\
\hline \multirow[t]{2}{*}{ Child } & -0.060 & -0.033 & -0.079 \\
\hline & $(0.044)$ & $(0.043)$ & $(0.054)$ \\
\hline \multirow[t]{2}{*}{ Joint } & 0.026 & $0.090^{* * *}$ & $0.099^{* *}$ \\
\hline & $(0.032)$ & $(0.026)$ & $(0.045)$ \\
\hline \multirow[t]{2}{*}{ Spouse } & -0.017 & -0.013 & 0.018 \\
\hline & $(0.035)$ & $(0.035)$ & $(0.043)$ \\
\hline \multicolumn{4}{|l|}{ Other characteristics } \\
\hline \multirow[t]{2}{*}{ Female } & 0.013 & -0.014 & 0.009 \\
\hline & $(0.039)$ & $(0.036)$ & $(0.057)$ \\
\hline \multirow[t]{2}{*}{ Diluted } & -0.012 & -0.002 & -0.018 \\
\hline & $(0.014)$ & $(0.014)$ & $(0.019)$ \\
\hline \multirow[t]{2}{*}{ Home bias } & $-0.172^{* * * *}$ & $-0.164^{* * *}$ & $-0.163^{* * *}$ \\
\hline & $(0.031)$ & $(0.031)$ & $(0.040)$ \\
\hline \multicolumn{4}{|l|}{ Legislative variables } \\
\hline \multirow[t]{2}{*}{ Legislative effectiveness score (LES) } & $0.034^{*}$ & 0.011 & 0.005 \\
\hline & $(0.019)$ & $(0.019)$ & $(0.025)$ \\
\hline \multirow[t]{2}{*}{ Finance Committee } & $0.097^{* * * *}$ & $0.076^{* * *}$ & $0.122^{* * *}$ \\
\hline & $(0.030)$ & $(0.030)$ & $(0.046)$ \\
\hline \multirow[t]{2}{*}{ Economic Committee } & 0.011 & 0.031 & 0.003 \\
\hline & $(0.058)$ & $(0.055)$ & $(0.076)$ \\
\hline \multirow[t]{2}{*}{ Energy Committee } & -0.015 & 0.031 & $0.150^{* * *}$ \\
\hline & $(0.040)$ & $(0.037)$ & $(0.056)$ \\
\hline \multirow[t]{2}{*}{ Commerce Committee } & -0.050 & -0.002 & 0.014 \\
\hline & $(0.034)$ & $(0.030)$ & $(0.052)$ \\
\hline \multirow[t]{2}{*}{ Number of bills } & $0.001^{*}$ & $0.001^{*}$ & $0.001^{*}$ \\
\hline & $(0.000)$ & $(0.000)$ & $(0.000)$ \\
\hline \multirow[t]{2}{*}{ Number of lobbyists } & $-0.000^{* * *}$ & $-0.000^{* * *}$ & $-0.000^{* * *}$ \\
\hline & $(0.000)$ & $(0.000)$ & $(0.000)$ \\
\hline Constant & 0.274 & $0.383^{* *}$ & -0.248 \\
\hline & $(0.188)$ & $(0.185)$ & $(0.241)$ \\
\hline
\end{tabular}


Firm control variables

Industry and year fixed effects

R-squared

Observation $(\mathrm{N})$

$\begin{array}{ccc}\text { Yes } & \text { Yes } & \text { Yes } \\ \text { Yes } & \text { Yes } & \text { Yes } \\ 0.115 & 0.112 & 0.168 \\ 5,288 & 5,288 & 2,797\end{array}$

Abnormal Idiosyncratic Volatility (AIV) computed over the five-day window. AIV corresponds to the standard definition of the AIV associated with the politicians' transactions, i.e., using equations (1)-(4), which excludes five days around the senators' transactions. (i.e., two days before, trading day and two days after the transaction). Control variables are similar to (Yang et al. 2020): Size ( $\log ($ market value of equity)), Book to Market, Illiquidity, past profitability, and market beta (12 months). Let us note that an alternative length (6 months) market beta provides very similar results. We report robust standard errors in parantheses. ${ }^{+}$for Senator tenure the base category (omitted dummy) is Tenure $14-35,{ }^{++}$for the age group the base category is Age $>65$, and ${ }^{+++}$for the account type the base category is Self. ${ }^{* * *},{ }^{* *}$, and ${ }^{*}$ denote statistical significance at $1 \%, 5 \%$ and $10 \%$, respectively. 
Table 7. Excess Market returns decomposition

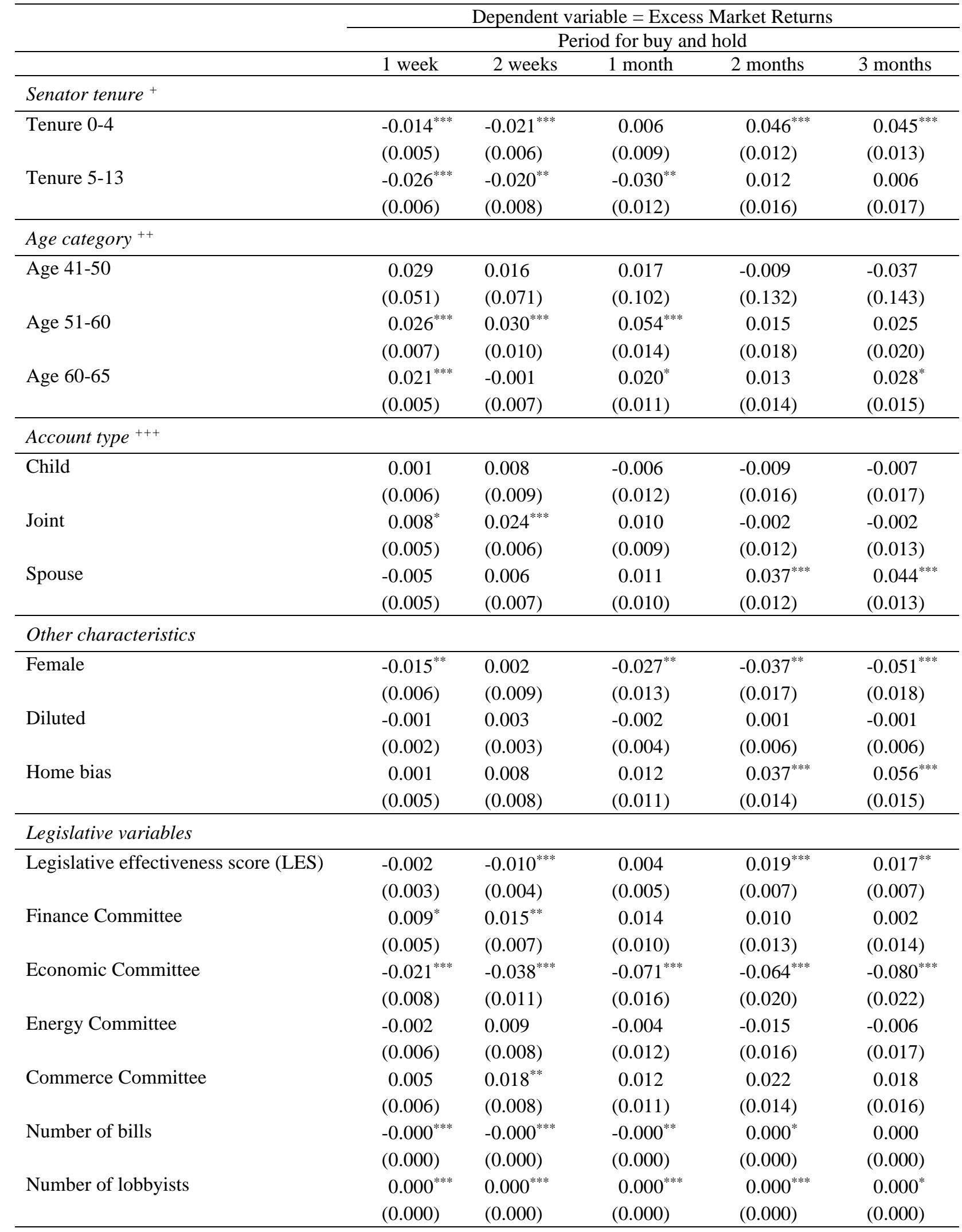




\begin{tabular}{lccccc}
\hline Constant & 0.039 & 0.027 & -0.010 & $-0.185^{*}$ & -0.054 \\
& $(0.040)$ & $(0.055)$ & $(0.079)$ & $(0.102)$ & $(0.110)$ \\
\hline Firm control variables & Yes & Yes & Yes & Yes & Yes \\
Industry and year fixed effects & Yes & Yes & Yes & Yes & Yes \\
R-squared & 0.0730 & 0.0875 & 0.1238 & 0.2027 & 0.2113 \\
Observation (N) & 2804 & 2804 & 2803 & 2803 & 2803 \\
\hline
\end{tabular}

The dependent variable is Senators Market Excess Return, columns correspond to the hold period. Abnormal market return is defined as the difference between stock return and S\&P500 index return. Control variables are similar to (Yang et al. 2020): Size (log(market value of equity)), Book to Market, Illiquidity, and past profitability. We report robust standard errors in parantheses. ${ }^{+}$for Senator tenure the base category (omitted dummy) is Tenure 14-35, ${ }^{++}$for the age group the base category is Age $>65$, and ${ }^{+++}$for the account type the base category is Self. ${ }^{* * *},{ }^{* *}$, and ${ }^{*}$ denote statistical significance at $1 \%, 5 \%$ and $10 \%$, respectively. 
Appendix 1 - Variable description

\begin{tabular}{|c|c|}
\hline Variables & Descriptions \\
\hline \multicolumn{2}{|l|}{ Dependent variables } \\
\hline AIV & $\begin{array}{l}\text { Measure of information asymmetry calculated as the difference } \\
\text { between annualized idiosyncratic volatility in the time window around } \\
\text { the transactions and the rest of the year. The time-window is } 5 \text { days } \\
\text { for each transaction- } 2 \text { days before, the transaction day, and } 2 \text { days } \\
\text { after. Data sources: CRISP and Compustat }\end{array}$ \\
\hline $\mathrm{AIV}_{\mathrm{F}}$ & $\begin{array}{l}\text { Defined identically as AIV with a different time window-the day of } \\
\text { the transaction and } 4 \text { days after it. }\end{array}$ \\
\hline $\mathrm{AIV}_{\mathrm{L}}$ & $\begin{array}{l}\text { Defined identically as AIV with a different time window-the day of } \\
\text { the transaction and } 4 \text { days before it. }\end{array}$ \\
\hline $\mathrm{AIV}_{\mathrm{E}}$ & $\begin{array}{l}\text { Measure of information asymmetry defined by Yang, Zhang \& Zhang } \\
\text { (2020). It is calculated as the difference between annualized } \\
\text { idiosyncratic volatility between the 5-day periods surrounding } \\
\text { earnings announcements and the rest of the year. }\end{array}$ \\
\hline Excess market returns & $\begin{array}{l}\text { Defined as the difference between stock return and the S\&P500 index } \\
\text { return over the specified period. Data sources: CRISP }\end{array}$ \\
\hline \multicolumn{2}{|l|}{ Senator tenure } \\
\hline $0-4$ & $\begin{array}{l}\text { Dummy variable that is equal one if the senator's tenure in the } \\
\text { specified year is between } 0 \text { and } 4\end{array}$ \\
\hline $5-13$ & $\begin{array}{l}\text { Dummy variable that is equal one if the senator's tenure in the } \\
\text { specified year is between } 5 \text { and } 13\end{array}$ \\
\hline $14-35$ & $\begin{array}{l}\text { Dummy variable that is equal one if the senator's tenure in the } \\
\text { specified year is between } 14 \text { and } 35\end{array}$ \\
\hline \multicolumn{2}{|l|}{ Age category } \\
\hline $41-50$ & $\begin{array}{l}\text { Dummy variable that is equal one if the senators age in the specified } \\
\text { year is between } 41 \text { and } 50\end{array}$ \\
\hline $51-60$ & $\begin{array}{l}\text { Dummy variable that is equal one if the senators age in the specified } \\
\text { year is between } 51 \text { and } 60\end{array}$ \\
\hline $60-65$ & $\begin{array}{l}\text { Dummy variable that is equal one if the senators age in the specified } \\
\text { year is between } 60 \text { and } 65\end{array}$ \\
\hline$>65$ & $\begin{array}{l}\text { Dummy variable that is equal one if the senators age in the specified } \\
\text { year is greater than } 65\end{array}$ \\
\hline \multicolumn{2}{|l|}{ Account type } \\
\hline Self & $\begin{array}{l}\text { Dummy variable that is equal to one if the trade occurred on the } \\
\text { senators' own account }\end{array}$ \\
\hline Child & $\begin{array}{l}\text { Dummy variable that is equal to one if the trade occurred on the } \\
\text { senators' child's account }\end{array}$ \\
\hline
\end{tabular}


Joint

Spouse
Dummy variable that is equal to one if the trade occurred on the senators joint account with their spouse

Dummy variable that is equal to one if the trade occurred on the senators' spouse's account
Other characteristics

Female

Diluted

Home bias
Dummy variable that is equal to one if the senator is female

We define a transaction as diluted if either a) the senator has made a transaction with a given security on the same day, or b) he has traded the same security in immediate subsequent trading days.

Dummy variable that is equal to one if the firm has headquarters in the state of the senator.

Legislative control variables

Legislative effectiveness score (LES)

Finance Committee

Economic Committee

Energy Committee

Commerce Committee

Number of bills

Number of lobbyists
Legislative effectiveness score is a measure of the legislative proficiency of each politician. The methodology along with the data can be found at https://thelawmakers.org/.

Dummy variable that is equal to 1 if the senator is part of the Finance committee.

Dummy variable that is equal to 1 if the senator is part of the Economic committee.

Dummy variable that is equal to 1 if the senator is part of the Energy and Natural Resources committee.

Dummy variable that is equal to 1 if the senator is part of the Commerce, Science, and Transportation committee.

The number of bills that were introduced on the day of the trade with at least one lobbyist. Source: OpenSecrets

Total number of lobbyists that are lobbying for laws introduced on the day of the trade. Source: OpenSecrets

Firm control variables

Past profitability

Group of variables $\mathrm{R}_{\mathrm{m}-1}, \mathrm{R}_{[\mathrm{m}-3, \mathrm{~m}-2]}, \mathrm{R}_{[\mathrm{m}-6, \mathrm{~m}-4]}, \mathrm{R}_{[\mathrm{m}-12, \mathrm{~m}-6]}$, which stand for return over the last month, month 3 to 2,6 to 4 , and 12 to 6 , respectively. Defined by Brennan et al. (2012). Data sources: CRISP and Compustat

Illiquidity

Defined as a sum of absolute values of daily returns divided by daily volume for the year, multiplied by $10^{\wedge} 6$. Defined by Amihud (2002). Data sources: CRISP and Compustat

Firm size

Defined as the natural logarithm of market value of equity. Data sources: CRISP and Compustat

Book-to-market ratio

Beta
Defined as book equity divided by market equity. Data sources: CRISP and Compustat

Calculated using Fama-French 3 factor model using the past 6 months of data. Data sources: CRISP and Compustat 
Appendix 2 - Results of tests for Abnormal Industry Returns of senators (buy and hold over selected periods)

\begin{tabular}{|c|c|c|c|c|c|c|c|c|}
\hline \multirow{2}{*}{ Hold period } & \multirow{2}{*}{ Statistical test } & \multicolumn{6}{|c|}{ Year of the recorded transaction } & \multirow{2}{*}{ Overall } \\
\hline & & 2014 & 2015 & 2016 & 2017 & 2018 & 2019 & \\
\hline \multirow[t]{2}{*}{ One week } & $t$-test & 0.001 & 0.001 & -0.002 & -0.002 & $-0.004^{* * *}$ & -0.001 & -0.002 \\
\hline & Sign test & $1.35^{* * *}$ & $1.32^{* * * *}$ & $1.28^{* * *}$ & $1.24^{* * *}$ & $0.69^{* * * *}$ & 1.17 & 0.98 \\
\hline \multirow[t]{2}{*}{ Two weeks } & $t$-test & -0.001 & -0.001 & $0.005^{* *}$ & -0.002 & $-0.006^{* * *}$ & 0.000 & -0.001 \\
\hline & Sign test & $1.38^{* * *}$ & 0.97 & $1.76^{* * *}$ & $1.38^{* * *}$ & 1.02 & $1.73^{* * *}$ & 0.99 \\
\hline \multirow[t]{2}{*}{ One month } & $t$-test & -0.004 & 0.005 & $0.011^{* * *}$ & $-0.004^{*}$ & $-0.013^{* * *}$ & -0.004 & -0.002 \\
\hline & Sign test & $1.76^{* * *}$ & 0.94 & $2.41^{* * *}$ & $1.69^{* * * *}$ & $0.76^{* * * *}$ & $2.08^{* * *}$ & $0.93^{* *}$ \\
\hline \multirow[t]{2}{*}{ Two months } & $t$-test & 0.000 & 0.002 & $0.01^{* * *}$ & -0.005 & $-0.015^{* * *}$ & $-0.011^{*}$ & -0.003 \\
\hline & Sign test & $1.80^{* * * *}$ & $0.76^{* * *}$ & $3.85^{* * *}$ & $1.84^{* * *}$ & 0.95 & $2.47^{* * *}$ & 0.98 \\
\hline \multirow[t]{2}{*}{ Three months } & $t$-test & -0.003 & $0.017^{* * * *}$ & 0.004 & $-0.009^{* * *}$ & $-0.011^{* * *}$ & -0.001 & -0.001 \\
\hline & Sign test & $2.04^{* * *}$ & $1.26^{* * *}$ & $5.27^{* * * *}$ & $2.08^{* * * *}$ & $1.34^{* * * *}$ & $2.15^{* * *}$ & 0.95 \\
\hline Number of observations & & 383 & 733 & 621 & 678 & 691 & 211 & 3317 \\
\hline
\end{tabular}

This table reports the results of tests for abnormal industry returns of senators for 5 different hold periods-from one week to three months. Abnormal industry return is defined as th difference between the stock return and the respective Fama-French 48 industry return. For each hold period the first row contains the results of the pairwise t-tests, while the second row contains the results of the sign test (also known as the median test), testing the hypothesis that the mean is equal to zero. For the sake of space, the sign test statistics recorded here are the ratio of positive/negative returns, with the significance of the relevant test. This means that positive and significant values of the t-test and values greater than one for the sign test support the hypothesis of positive excess returns. The first two years (2012 and 2013) have very few observations and therefore the results for these years are not presented. The number of observations is related to the longest buy-and-hold period, i.e., the number of observations for three months. It also represents the minimum number of observations across all holding periods. Since our stock returns data ends December 31,2019, and hence there are no observations for 2020 and a lower number for 2019. ${ }^{* * *},{ }^{* *}$, and ${ }^{*}$ denote statistical significance at $1 \%, 5 \%$ and $10 \%$, respectively. 
Appendix 3: Non-informativeness of sell transactions

\begin{tabular}{|c|c|c|c|c|c|c|c|}
\hline Hold Period & 2014 & 2015 & 2016 & 2017 & 2018 & 2019 & Overall \\
\hline One week & $-0.541^{* *}$ & $1.298^{* * *}$ & $0.508^{*}$ & 0.328 & $1.338^{* * *}$ & 0.19 & $0.679^{* * *}$ \\
\hline Two weeks & $-1.373^{* * *}$ & $2.823^{* * * *}$ & $2.074^{* * *}$ & $0.512^{*}$ & $2.604^{* * * *}$ & 0.552 & $1.556^{* * *}$ \\
\hline One month & $-1.722^{* * * *}$ & $3.062^{* * *}$ & $5.617^{* * * *}$ & $1.131^{* * * *}$ & $3.646^{* * *}$ & 0.857 & $2.622^{* * *}$ \\
\hline Two months & $-2.288^{* * * *}$ & $2.846^{* * * *}$ & $9.781^{* * *}$ & $1.161^{*}$ & $4.671^{* * * *}$ & $5.231^{* * * *}$ & $3.896^{* * *}$ \\
\hline Three months & $-3.917^{* * *}$ & $5.303^{* * *}$ & $11.642^{* * * *}$ & $1.738^{* * *}$ & $8.773^{* * *}$ & $8.499^{* * *}$ & $5.84^{* * *}$ \\
\hline Observations & 304 & 579 & 518 & 471 & 582 & 187 & 2641 \\
\hline
\end{tabular}

In this table we show t-test results of the differences between buy and hold returns on senators' investment and the return of stocks the senator most recently sold if that sale happened within a week of the purchase. Positive and significant results suggest that stocks that senators purchase perform better than those they just sold, suggesting that the primary motivation for selling for senators is the securing of profits and need for liquidity. The first two years (2012 and 2013) have very few observations and as a result have been omitted. ${ }^{* * *},{ }^{* *}$, and ${ }^{*}$ denote statistical significance at $1 \%, 5 \%$ and $10 \%$, respectively. 